Buana Sains Vol 19 No $2: 53$ - 78, 2019

\title{
FAKTOR-FAKTOR YANG MEMPENGARUHI TINGKAT PENDAPATAN RUMAH TANGGA TANI DI KOTA BATU (Studi di Desa Tlekung Kecamatan Jonreju Kota Batu)
}

\author{
Johanis Nifanngeljau, Muhamad Rifa'i, dan Nur Ida Iriani \\ Sekolah Pasca Sarjana Program Studi Ekonomi Pertanian \\ Universitas Tribhuwana Tunggadewi Malang
}

\begin{abstract}
Human resources are very important and must be had in an effort to achieve goals. Human resources are the main element for individuals who compare with other elements, which are supported to develop the existing potential. Capital resources or capital is one means to support the production process of an item or service. Capital does not only consist of technological money, equipment, machinery, land, information, and so on, including capital because it can support the production process. With the capital, the production process will become easier and more efficient, for example, the use of tractors by farmers will increase land management by other manual and traditional methods.

Natural resources are resources derived from nature, they can be obtained as valuable goods or services. For example in planting patches in an area will make this area a producer of food or vegetables will be very beneficial for humans if it can be processed properly. In this study, the dominant or significant factor related to human resources has a significant $0,000<0.05$ with a standard coefficient of 0.680 or contributes to farm household income of $68.0 \%$. Capital resources have significant ownership of $0.001<0.05$ with a standard coefficient of 0.526 or contribute to farm household income by $52.6 \%$. While natural resources have significant ownership of $0,000<0.05$ with a standard coefficient of 0.712 or contribute to farm household income of $71.2 \%$. To make this refutation, it is necessary to re-evaluate the group in Tlekung Village, Jonrejo Subdistrict, Batu City, which are human resources, capital resources, and natural resources.
\end{abstract}

Keywords: Capital resources; human resources; natural resources; social capital; tlekung village.

\section{Pendahuluan}

Sumber Daya Manusia (SDM) adalah individu produktif yang bekerja sebagai penggerak suatu organisasi, baik itu di dalam institusi maupun pada kelembagaan pertanian yang memiliki fungsi sebagai aset sehingga harus dilatih dan dikembangkan kemampuannya (Fukuyama, 2000). Sumber daya manusia perlu di tingkatkan di kalangan petani saat ini salah satunya pendidikan menurut jalurnya terdiri atas pendidikan formal, nonformal dan informal. Pendidikan formal meliputi jenjang pendidikan yakni, dasar, menengah dan pendidikan tinggi. Jenis pendidikan ini berupa pendidikan umum, kejuruan, akademik, profesi, vokasi, keagamaan dan khusus.

Aset fisik rumah tangga, seperti, bagi rumah tangga pedesaan 
yang hanya menguasai faktor produksi tenaga kerja, pendapatan mereka ditentukan oleh besarnya kesempatan kerja yang dapat dimanfaatkan dan tingkat upah yang diterima. Kedua faktor ini merupakan fenomena dari pasar tenaga kerja pedesaan. Kesempatan kerja pedesaan ditentukan oleh pola produksi pertanian, produksi dan jasa nonpertanian pedesaan, pertumbuhan angkatan kerja, dan mobilitas tenaga kerja pedesaan. Di sektor pertanian besarnya kesempatan kerja dipengaruhi oleh luas lahan pertanian. Masyarakat pedesaan di keempat desa contoh merupakan hasil dari dinamika tatanan sejarah budaya dan ekologi agraris masyarakat Jawa pedesaan di dua lokasi penelitian, menurut (Lombart, 2000).

Ini menunjukkan bahwa keberadaan masyarakat pedesaan tidak sekedar adanya sekumpulan manusia yang secara fisik telah hidup bersama dalam kurun tertentu, melainkan ada "semangat" atau ruh sosial yang menjadi kekuatan pengikat kehidupan kolektif mereka. Kekuatan budaya nonmaterial atau modal sosial menjadi faktor penting mengapa masyarakat di keempat desa contoh hingga sekarang masih bisa bertahan.

Pembangunan sarana dan prasarana fisik di lingkungan desa, terutama akses perhubungan dan transportasi, masih perlu diperhatikan. Infrastuktur jalan di pedesaan masih memerlukan penataan pembangunan yang lebih baik untuk menambah jenis permukaan aspal untuk memudahkan mobilitas penduduk guna mengembangkan potensi ekonomi setempat.

\section{Metode Penelitian}

Penelitian dilakukan di Kecamatan Junrejo, Desa Tlekung kota Batu kerena pada dasarnya kota
Batu dikenal sebagai kota wisata disisi lain kota Batu juga dikenal dengan sumber daya alamnya sangat luas sehingga salah satu mata pencarian para petani adalah bercocok tanam.

Penelitian yang dilakukan merupakan penelitian dengan menggunakan metode kuantitatif, karena penelitian ini menyoroti hubungan antara variabel penelitian dan menguji hipotesis yang telah dirumuskan dengan fokus yang terletak pada penjelasan hubungan antara variabel. penelitian ini juga menguji teori-teori dengan melalui pengukuran variable penelitian ini dengan angka dan melakukan analisis dengan data melalui prosudur statistik. Dalam penelitian ini menjelaskan Faktor-Faktor Yang Mempengaruhi Tingkat Pendapatan Rumah Tangga Tani Di Kota Batu.

\section{Sumber Data}

Sumber data dalam penelitian ini dapat dibagi menjadi 2 bagian diantaranya :

\section{a. Data Primer}

Data primer adalah data yang diperoleh secara langsung dari petani di kota Batu melalui wawancara secara langsung (Intrerview). Contohnya jumlah petani yang ada di kota Batu atau mengajukan kuisioner kepada responden dan observasi secara langsung yang menyangkut tentang apa saja yang mempengaruhi faktorfaktor yang mempengaruhi tingkat pendapatan rumah tangga tani di kota Batu.

\section{b. Data Sekunder}

Data sekunder diperoleh dengan berbagai sumber-sumber lain yang berkaitan dengan apa yang akan diteliti dan menyangkut dalam penelitian. Data sekunder dalam penelitian ini yang berkaitan dengan faktor-faktor yang mempengaruhi tingkat pendapatan rumah tangga tani 
Di Kota Batu. Data yang dibutuhkan antara lain sejarah dan perkembangan petani.

\section{Teknik Pengumpulan Data}

Penelitian ini menggunakan beberapa langkah dalam pengumpulan data, diantaranya:

1. Dokumentasi

Metode ini dilakukan untuk mendapatkan data sekunder sebagai data pendukung dari penelitian ini dan mempelajari dokumen-dokumen yang ada pada petani yang berhubungan dengan penelitian, untuk melengkapi penelitian, peneliti mengambil data sekunder berupa profil lahan yang terdapat didesa Tlekung .

2. Kuesioner

Kuesioner yang akan menjadi data kuantitatif peneliti, kuesioner ini yang akan dibagi kepada responden dan akan dikembalikan lagi kepada peneliti kemudian peneliti akan menganalisis data tersebut dengan menggunakan teknik analisis data tersebut.

\section{Populasi dan Sampel}

\section{Populasi Penelitian}

Populasi adalah seluruh kumpulan elemen yang menunjukkan ciri-ciri tertentu yang dapat digunakan untuk membuat kesimpulan (Sanusi, 2011). Populasi dalam penelitian ini adalah petani yang tergabung dalam gapoktan sebanyak 10 kelompok tani yang berada di desa Tlekung yang terdapat didalamnya 20 angota per kelompok tani. Sehinga jumlah keseluruan gapoktan di desa Tlekung Kota Batu sebanyak 200 orang.

\section{Sampel Penelitian}

Menurut Sugiono (2007:116), sampel adalah bagian dari jumlah karakteristik yang dimiliki dari populasi tersebut. Sampel yang digunakan dalam penelitian ini adalah jenis purposive sampling, yaitu teknik penentuan sampel dengan tujuan peneliti. Unit sampel yang dipakai yang disesuaikan dengan komponen kelompok tani di kecamatan junrejo desa Tlekung di kota Batu sebanyak 58 gapoktan di kecamatan Junrejo desa Tlekung kota Batu. Untuk memenuhi jumlah sampel dalam penelitian ini menggunakan rumus sebagai berikut:

$$
\begin{aligned}
& \mathrm{n}=\frac{N}{1+N(e)^{2}} \\
& \text { Dimana: } \\
\mathrm{n}= & \text { Ukuran populasi } \\
\mathrm{N}= & \text { Ukuran sampel } \\
\mathrm{E}= & \text { Prosentasi kelonggaran pada } \\
& \text { ketidaktelitian karena terdapat } \\
\text { kesalahan pada pengambilan } & \text { sampel yang masih dapat } \\
& \text { ditolerir yaitu 10\% }(0.1) .
\end{aligned}
$$

\section{Variabel Penelitian dan Tipe Pengukuran Variabel}

Sanusi (2011) mendefinisikan variabel independen yaitu : aturan etika, profesionalisme dan independensi adalah variabel yang dipengaruhi oleh variabel lain, sedangkan variabel dependen adalah pendapatan rumah tangga tani adalah variabel yang mempengaruhi variabel lain. Variabel yang digunaka dalam penelitian ini adalah variabel bebas (X) dan variabel terikat $(\mathrm{Y})$.

1. Variabel bebas (X) adalah variabel yang tidak dipengaruhi oleh variabel lain. Dalam penelitian ini variabel bebas terdiri empat variabel yaitu :

- Sumber Daya Manusia

- Sumber Daya Kapital

- Modal Sosial

- Sumber Daya Alam

2. Variabel terikat $(\mathrm{Y})$ yaitu variabel yang dipengaruhi oleh variabel yang lain. Dalam penelitian ini variabel terikat $(\mathrm{Y})$ adalah :

- Pendapatan Rumah tangga Tani Di Kota Batu 


\section{Teknik Analisis Data}

Menurut Sugiyono (2007:206), statistik deskriptif adalah statistik yang digunakan untuk menganalisis data dengan cara mendeskripsikan atau menggambarkan data yang telah ada terkumpul sebagaimana adanya tanpa bermaksud membuat kesimpulan yang berlaku untuk umum. Dalam statistik deskriptif antara lain adalah penyajian data melalui tabel, grafik diagram lingkaran, dan perhitungan porsentase.

\section{Pengujian Keabsahan Data}

\section{Uji Validitas}

Uji validitas item pertanyaan dilakukan dengan tujuan untuk mengetahui keandalan angket. Keandalan angket terdapat tiga jenis validitas yaitu validitas isi, validitas konstruk dan validitas yang berkaitan dengan kriteria. Dalam penelitian ini juga uji validitas yang digunakan adalah uji validitas kanstruk yang mengkorelasikan masing-masing item pertanyaan dengan skor totalnya. Pengukuran validitas dalam penelitian ini menunjukan nilai varian dan indikator yang diekstrasi oleh konstruks/variabel item yang dikembangkan, kemudian hasil korelasi dibandingkan dengan nilai kritis pada nilai signifikansi 0,05.

Adapun perhitungan korelasi Product moment, denganrumus yang ditemukan oleh Arikunto (2014)

$$
\begin{aligned}
& r_{x y}=\frac{n \Sigma \dot{x} y-(\Sigma x, \Sigma y)}{\sqrt{\left.\left.[n \Sigma x)^{2}\right][n \Sigma y-\Sigma y)^{2}\right]}} \\
& =(3.3)
\end{aligned}
$$

Dimana:

$\mathrm{r}=$ Koefisien korelasi antara $\mathrm{X}$ dan $\mathrm{Y}$

$\mathrm{n}=$ Banyaknya pertanyaan

$\mathrm{x}=$ Skor masing-masing item

$\mathrm{y}=$ Skor total variabel

\section{Uji Reabilitas}

Menurut Siregar (2013: 87) reliabilitas bertujuan untuk mengetahui sejauh mana hasil pengukuran tetap konsisten, apabila dilakukan pengukuran dua kali atau lebih terhadap gejala yang sama dengan menggunakan alat pengukur yang sama pula. Silalahi (2009: 238) menambahkan bahwa suatu alat ukur memiliki reliabilitas atau keandalan, atau dapat dipercaya jika hasil pengukuran dari alat ukur tersebut stabil atau konsisten. Cara mencari reliabilitas untuk keseluruhan item salah satunya bisa dilakukan dengan mengunakan koefisien Alpha Cronbach yang dirumuskan sebagai berikut:

$$
\left.\alpha=\frac{k}{[(k k-1)}\right]\left[1-\frac{\square \sigma b^{2}}{\sigma b^{2}}\right]
$$

Keterangan:

$\alpha \quad=$ Reliabilitas Instrumen

$\mathrm{K}$ = Banyaknya butir pertanyaan

$\Sigma \sigma b^{2}=$ Jumlah varians butir

$\sigma b^{2}=$ Varians total pendekatan

\section{Teknik Analisa Data}

\section{Analisa Deskritif}

Sujianto (2009:23) menjelaskan bahwa analisis deskriptif lebih "berhubungan dengan pengumpulan dan peringkasan data, serta penyajian hasil peringkasan tersebut". Data tersebut umumnya masih acak, mentah dan tidak terorganisasi dengan baik. Analisis deskriptif digunakan untuk memberikan gambaran umum tentang data yang diperoleh. Gambaran umum ini bisa menjadi acuan untuk melihat karakteristik data yang diperoleh. Data yang terkumpul secara keseluruhan kemudian diolah dan ditabulasikan ke dalam tabel frekuensi. Tabel frekuensi ini sangat menopang dalam mendeskripsikan variabel yang terdiri dari Sumber Daya 
Manusia $\left(\mathrm{X}_{1}\right)$, Sumber Daya Kapital $\left(\mathrm{X}_{2}\right)$, Modal Sosial $\left(\mathrm{X}_{3}\right)$, Sumber Daya Alam $\left(\mathrm{X}_{4}\right)$ dan Pendapatan Rumah Tangga Tani $(\mathrm{Y})$

\section{Uji Asumsi Klasik}

Hipotesis dalam penelitian ini menggunakan alat analisis regresi berganda (multiple regression), syarat yang dianjurkan sebelum melakukan analisis regresi linier berganda terlebih dulu dilakukan uji asumsi klasik yang terdiri dari:

\section{a. Uji Normalitas}

Uji normalitas bertujuan untuk menguji apakah dalam model regresi, variabel pengganggu atau residual terdistribusi normal (Ghozali, 2011). Penggunaan uji normalitas karena pada analisis statistik parametik yaitu analisis regresi berganda, asumsi yang harus dimiliki data adalah bahwa data tersebut harus terdistribusi secara normal. Uji asumsi ini digunakan untuk menguji data variabel bebas $(\mathrm{X})$ dan data variabel terikat (Y) pada persamaan regresi yang dihasilkan, apakah data tersebut berdistribusi secara normal atau tidak normal (Sunyoto, 2009:84). Persamaan regresi dikatakan baik jika mempunyai data variabel bebas dan data variabel terikat berdistribusi mendekati normal. Uji normalitas data menggunakan Kolmogrov-Sminov Test, dengan membandingkan asymptotic significance dengan alpha 0,05 .

\section{b. Uji Multikolinearitas}

Uji multikolonearitas untuk menguji apakah model regresi ditemukan adanya korelasi antar variabel bebas (independen). Model regresi yang baik seharusnya tidak terjadi korelasi di antara variabelvariabel independen. Menurut Sunyoto (2009:82) apabila nilai VIF < 10 maka tidak terjadi multikoliniearitas.

\section{c. Analisis Heteroskedastisitas}

Uji heterokedastisitas adalah pengujian untuk menguji apakah model regresi terjadi ketidaksamaan varians dari satu pengamatan ke pengamatan lain. Heterokedastisitas dapat dilihat jika ada pola tertentu yaitu titik-titik yang membentuk pola tertentu yang teratur (Ghozali, 2011).

\section{d. Uji Autokorelasi}

Uji Autokorelasi digunakan untuk mengetahui apakah ada atau tidaknya penyimpangan asumsi klasik autokorelasi, yaitu korelasi yang terjadi antara residual pada suatu pengamatan dengan lain pada model regresi. Prasyarat yang harus terpenuhi adalah tidak adanya autokorelasi dalam model regresi. Metode pengujian yang sering digunakan adalah dengan Uji DurbinWatson (uji DW).

\section{Analisa Regresi}

\section{a. Uji Regresi Berganda}

Analisis regresi dalam statistika adalah salah satu metode untuk menentukan hubungan sebab-akibat antara satu variabel dengan variabelvariabel yang lain. Menurut Ghozali (2011) persamaan regresi linear berganda dapat dinyatakan sebagai berikut:

$\mathrm{Y}=\mathrm{a}+\mathrm{b} 1 \mathrm{X} 1+\mathrm{b} 2 \mathrm{X} 2+\mathrm{b} 3 \mathrm{X} 3+\mathrm{b} 4 \mathrm{X} 4+\mathrm{e}$ Keterangan:

Y : Pendapatan Rumah Tangga Tani

$\mathrm{X}_{1}$ : Sumber Daya Manusia

$\mathrm{X}_{2}$ : Sumber Daya Kapital

$\mathrm{X}_{3}$ : Modal Sosial

$\mathrm{X}_{4}$ :Sumber Daya Alam

a : Konstanta

e : Error

\section{b. Analisis Korelasi Ganda (R)}

Analisis korelasi ganda dimaksudkan untuk mengetahui kuat tidaknya hubungan antara dua atau lebih variabel independen (X) 
terhadap variabel dependen $(\mathrm{Y})$ secara bersama-sama.

\section{c. Analisis Koefisien Determinasi}

Analisis koefisien determinasi (R Square) dalam analisis linear berganda digunakan untuk mengetahui prosentase pengaruh variabel independen (X) terhadap variabel dependen (Y). Koefisien ini menunjukan seberapa besar prosentase variasi variabel independen yang digunakan dalam model mampu menjelaskan variabel dependen (Y). Sedangkan Adjusted R Square adalah nilai R Square yang telah disesuaikan.

\section{d. Uji Hipotesis}

\section{Uji F (Uji Hipotesisi pertama)}

Uji ini digunakan untuk mengetahui apakah variabel-variabel independen (X) secara bersama-sama berpengaruh secara signifikan terhadap variabel dependen $(\mathrm{Y})$ atau untuk mengetahui apakah model regresi dapat digunakan untuk memprediksi variabel dependen atau tidak. Menurut Simamora (2004:342) Uji $F$ dapat dihitung dengan menggunakan rumus sebagai berikut:

$$
\mathrm{F} \quad=\frac{R^{2} / k}{\left(1-R^{2} /(n-k-1)\right.} /
$$

$\mathrm{F}=$ Rasio

Keterangan:

$\mathrm{R}=$ Korelasi ganda

$\mathrm{k}=$ Jumlah variabel bebas

$\mathrm{n}=$ Jumlah Sampel

\section{Uji t (Uji Hipotesis Kedua)}

Uji ini dilakukan untuk mengetahui apakah dalam model regresi variabelvariabel independen (X) secara parsial berpengaruh signifikan terhadap variabel dependen (Y).

\section{Hasil dan Pembahasan}

\section{Karakteristik Responden Berdasarkan Jenis Kelamin}

Karakteristik responden berdasarkan jenis kelamin terdapat pada tabel 1.

Tabel 1. Karakteristik Responden Berdasarkan Jenis Kalamin

\begin{tabular}{|l|c|c|}
\hline $\begin{array}{c}\text { Jenis } \\
\text { Kelamin }\end{array}$ & Frekuensi & Persentase \\
\hline Laki-Laki & 20 & 34,5 \\
\hline Perempuan & 38 & 65,5 \\
\hline Total & 58 & 100,0 \\
\hline
\end{tabular}

Sumber: Data Primer Diolah 2019

Berdasarkan tabel di atas, dapat diketahui bahwa responden yang berjenis kelamin laki-laki sebanyak 20 responden atau 34,5\%, sedangkan jumlah perempun sebanyak 38 Responden atau $65,5 \%$.

2. Karakteristik Responden Berdasarkan Tingkat Pendidikan Karakteristik responden berdasarkan tingkat pendidikan terdapat pada tabel 2. Berdasarkan tabel dibawah ini, dapat diketahui bahwa responden yang berdasarkan tingkat pendidikan SMP sebanyak 14 responden atau $24,1 \%$, SMA dengan jumlah responden sebanyak 15 Responden atau 25,9\%, D3 berjumlah 14 orang responden atau $24,1 \%$ sedangkan S1 berjumlah 15 orang responden atau 25,9\%. Kondisi responden dilihat dengan tingkat pendidikan ini dimaksudkan untuk melihat permasalahan mengenai faktor-faktor yang mempengaruhi tingkat pendapatan rumah tangga tani Studi di Desa Tlekung.

Tabel 2. Karakteristik responden berdasarkan tingkat pendidikan

\begin{tabular}{|l|c|c|}
\hline Pendidikan & Frekuensi & Persentase \\
\hline SMP & 14 & 24,1 \\
\hline SMA & 15 & 25,9 \\
\hline D3 & 14 & 24,1 \\
\hline S1 & 15 & 25,9 \\
\hline Total & 58 & 100,0 \\
\hline
\end{tabular}

Sumber: Data Primer Diolah 2019 
3. Karakteristik

Berdasarkan Usia

Karakteristik responden berdasarkan usia terdapat pada tabel 3. Berdasarkan tabel 3, dapat diketahui bahwa responden yang berdasarkan tingkat usi 20-25 tahun sebanyak 13 responden reponden atau 22,4\%, 27-30 tahun sebanyak 2 Responden atau 3,4\%, 35-40 Tahun 17 orang responden atau $29,3 \%, 40$ 50 tahun sebanyak 21 orang atau $36,2 \%$, sedangkan usia 50-61 tahun 5 orang atau $8,6 \%$.

4. Karakteristik Responden Berdasarkan status pernikahan Karakteristik responden berdasarkan status pernikahan terdapat pada tabel 4. Berdasarkan tabel 4, dapat diketahui bahwa responden yang berdasarkan status belum menikah sebanyak 22 orang responden atau 37,9\%, sedangkan yang menikah berjumlah 36 orang responden atau $62,1 \%$.

Tabel 3. Karakteristik Responden Berdasarkan usia

\begin{tabular}{|l|c|c|}
\hline \multicolumn{1}{|c|}{ Status } & Frekuensi & Persentase \\
\hline $\begin{array}{l}20-25 \\
\text { Tahun }\end{array}$ & 13 & 22,4 \\
\hline $\begin{array}{l}27-30 \\
\text { Tahun }\end{array}$ & 2 & 3,4 \\
\hline $\begin{array}{l}35-40 \\
\text { Tahun }\end{array}$ & 17 & 29,3 \\
\hline $\begin{array}{l}40-50 \\
\text { Tahun }\end{array}$ & 21 & 36,2 \\
\hline $\begin{array}{l}50-61 \\
\text { Tahun }\end{array}$ & 5 & 8,6 \\
\hline Total & 58 & 100,0 \\
\hline
\end{tabular}

Sumber: Data Primer Diolah 2019
Tabel 4. Karakteristik Responden

Berdasarkan status pernikahan

\begin{tabular}{|l|c|c|}
\hline \multicolumn{1}{|c|}{ Status } & Frekuensi & Persentase \\
\hline $\begin{array}{l}\text { Belum } \\
\text { Menikah }\end{array}$ & 22 & 37,9 \\
\hline Menikah & 36 & 62,1 \\
\hline Total & 58 & 100,0 \\
\hline
\end{tabular}

Sumber: Data Primer Diolah 2019

5. Karakteristik Responden Berdasarkan Penghasilan

Karakteristik responden berdasarkan status pernikahan terdapat pada tabel 5. Berdasarkan tabel 5, dapat diketahui bahwa responden yang berdasarkan tingkat pendapatan $\mathrm{Rp}$ $1.000 .000-2.000 .000$ sebanyak 5 orang responden atau 8,6\%, Rp 3.000 .000 3.500 .000 sebanyak 11 orang responden atau $19,0 \%$, Rp 4.000.000 - 4.750 .000 berjumlah 14 orang ressponden atau $24,1 \%$ sedangkan Rp 5.000 .000 berjumlah 28 orang responden atau 48,3\%.

Tabel 5. Karakteristik Responden Berdasarkan Penghasilan

\begin{tabular}{|l|c|c|}
\hline \multicolumn{1}{|c|}{ Penghasilan } & Frekuensi & Persentase \\
\hline $\begin{array}{l}\text { Rp 1.000.000 - } \\
2.000 .000\end{array}$ & 5 & 8,6 \\
\hline $\begin{array}{l}\text { Rp 3.000.000 - } \\
3.500 .000\end{array}$ & 11 & 19,0 \\
\hline $\begin{array}{l}\text { Rp 4.000.000 - } \\
4.750 .000\end{array}$ & 14 & 24,1 \\
\hline Rp 5.000.000 & 28 & 48,3 \\
\hline Total & 58 & 100,0 \\
\hline
\end{tabular}

Sumber: Data Primer Diolah 2019

\section{Pengujian Keabsahan Data}

\section{Hasil Uji Validitas Dan Reabilitas}

Berikut adalah tabel hasil uji validitas dan reliabilitas yang telah dikelompokkan per variabel dengan jumlah responden sebanyak 57 orang. 
Tabel 6. Hasil Uji Validitas Dan Reabilitas Variabel Sumber Daya Manusia X

\begin{tabular}{|c|c|c|c|}
\hline Item & Koefisien & Korelasi (r) & Probabilitas \\
\hline $\mathrm{X}_{1} \cdot 1$ & 0,789 & 0,000 & Valid \\
\hline $\mathrm{X}_{1} \cdot 2$ & 0,489 & 0,000 & Valid \\
\hline $\mathrm{X}_{1} \cdot 3$ & 0,551 & 0,000 & Valid \\
\hline $\mathrm{X}_{1} \cdot 4$ & 0,378 & 0,000 & Valid \\
\hline $\mathrm{X}_{1} \cdot 5$ & 0,378 & 0,000 & Valid \\
\hline $\mathrm{X}_{1} \cdot 6$ & 0,573 & 0,000 & Valid \\
\hline \multicolumn{2}{|l|}{ Aplha Cronbach } & 0,700 & Reliabel \\
\hline
\end{tabular}

Tabel 7. Hasil Uji Validitas Dan Reabilitas Variabel Sumber Daya Kapital X

\begin{tabular}{|c|c|c|c|}
\hline Item & Koefisien & Korelasi $(\mathrm{r})$ & Probabilitas \\
\hline $\mathrm{X}_{1} \cdot 1$ & 0,893 & 0,000 & Valid \\
\hline $\mathrm{X}_{1} \cdot 2$ & 0,849 & 0,003 & Valid \\
\hline $\mathrm{X}_{1} \cdot 3$ & 0,893 & 0,000 & Valid \\
\hline $\mathrm{X}_{1} \cdot 4$ & 0,849 & 0,000 & Valid \\
\hline $\mathrm{X}_{1} \cdot 5$ & 0,893 & 0,000 & Valid \\
\hline $\mathrm{X}_{1} \cdot 6$ & 0,440 & 0,001 & Valid \\
\hline \multicolumn{2}{|l|}{ Aplha Cronbach } & 0,898 & Reliabel \\
\hline
\end{tabular}

Tabel 8. Hasil Uji Validitas Dan Reabilitas Variabel Modal Sosial $\mathrm{X}_{3}$

\begin{tabular}{|c|c|c|c|}
\hline Item & Koefisien & Korelasi $(\mathrm{r})$ & Probabilitas \\
\hline $\mathrm{X}_{1} \cdot 1$ & 0,539 & 0,000 & Valid \\
\hline $\mathrm{X}_{1} \cdot 2$ & 0,691 & 0,000 & Valid \\
\hline $\mathrm{X}_{1} \cdot 3$ & 0,761 & 0,000 & Valid \\
\hline $\mathrm{X}_{1} \cdot 4$ & 0,768 & 0,000 & Valid \\
\hline $\mathrm{X}_{1} \cdot 5$ & 0,217 & 0,000 & Valid \\
\hline $\mathrm{X}_{1} \cdot 6$ & 0,721 & 0,000 & Valid \\
\hline \multicolumn{2}{|l|}{ Aplha Cronbach } & 0,831 & Reliabel \\
\hline
\end{tabular}

Berdasarkan tabel 6 menunjukkan hasil uji validitas dan reliabilitas dari variabel Sumber Daya Manusia $\left(\mathrm{X}_{1}\right)$. Hasil uji validitas menunjukkan bahwa semua item dari variabel Sumber Daya Manusia yang terdiri dari 6 item pernyataan memiliki koefisien korelasi di bawa 0,005 sehingga angket dinyatakan valid. Sementara itu hasil uji reliabilitas menunjukkan bahwa nilai Alpha Cronbach sebesar sebesar 0,700 dimana nilai tersebut lebih besar dari 0,005 sehingga seluruh item pada variabel Sumber Daya Manusia dapat dinyatakan reliabel.

Berdasarkan tabel 7 diketahui hasil uji validitas dan reliabilitas dari variabel Sumber Daya Kapital $\left(\mathrm{X}_{2}\right)$. Hasil uji validitas menunjukkan bahwa semua item dari variabel Sumber Daya Kapital yang terdiri dari 6 item pernyataan memiliki koefisien korelasi di bawa 0,005 sehingga angket dinyatakan valid. Sementara itu hasil uji reliabilitas menunjukkan bahwa nilai Alpha Cronbach sebesar sebesar 0,898 dimana nilai tersebut lebih besar 
dari 0,005 sehingga seluruh item pada variabel Sumber Daya Kapital dapat dinyatakan reliabel.

Berdasarkan tabel 8, diketahui hasil uji validitas dan reliabilitas dari variabel Modal Sosial $\left(\mathrm{X}_{3}\right)$. Hasil uji validitas menunjukkan bahwa semua item dari variabel Modal Sosial yang terdiri dari 6 item pernyataan memiliki koefisien korelasi di bawa 0,005 sehingga angket dinyatakan valid. Sementara itu hasil uji reliabilitas menunjukkan bahwa nilai Alpha Cronbach sebesar sebesar 0,831 dimana nilai tersebut lebih besar dari 0,005 sehingga seluruh item pada variabel Modal Sosial dapat dinyatakan reliabel.

Berdasarkan tabel 9, menunjukkan hasil uji validitas dan reliabilitas dari variabel Sumber Daya Alam $\left(X_{4}\right)$. Hasil uji validitas menunjukkan bahwa semua item dari variabel Sumber Daya Alam yang terdiri dari 6 item pernyataan memiliki koefisien korelasi di bawa 0,005 sehingga angket dinyatakan valid. Sementara itu hasil uji reliabilitas menunjukkan bahwa nilai Alpha Cronbach sebesar sebesar 0,793 dimana nilai tersebut lebih besar dari 0,005 sehingga seluruh item pada variabel Sumber Daya Alam dapat dinyatakan reliabel.

Berdasarkan tabel 10 dapat diketahui bahwa hasil uji validitas dan reliabilitas dari variabel Pendapatan Rumah Tangga Tani Y. Hasil uji validitas menunjukkan bahwa semua item dari variabel Pendapatan Rumah Tangga Tani yang terdiri dari 6 item pernyataan memiliki koefisien korelasi di bawa 0,005 sehingga angket dinyatakan valid. Sementara itu hasil uji reliabilitas menunjukkan bahwa nilai Alpha Cronbach sebesar sebesar 0,730 dimana nilai tersebut lebih besar dari 0,005 sehingga seluruh item pada variabel Pendapatan Rumah Tangga Tani dapat dinyatakan reliabel.

Tabel 9. Hasil Uji Validitas Dan Reabilitas Variabel Sumber Daya Alam X 4

\begin{tabular}{|l|c|c|l|}
\hline Item & Koefisien & Korelasi $(\mathrm{r})$ & Probabilitas \\
\hline $\mathrm{X}_{1} \cdot 1$ & 0,835 & 0,000 & Valid \\
\hline $\mathrm{X}_{1} \cdot 2$ & 0,591 & 0,000 & Valid \\
\hline $\mathrm{X}_{1} \cdot 3$ & 0,835 & 0,000 & Valid \\
\hline $\mathrm{X}_{1} \cdot 4$ & 0,809 & 0,000 & Valid \\
\hline $\mathrm{X}_{1} \cdot 5$ & 0,544 & 0,000 & Valid \\
\hline $\mathrm{X}_{1} \cdot 6$ & 0,544 & 0,000 & Valid \\
\hline \multicolumn{2}{|l|}{ Aplha Cronbach } & 0,793 & Reliabel \\
\hline
\end{tabular}

Tabel 10. Hasil Uji Validitas Dan Reabilitas Variabel Pendapatan Rumah Tangga Tani Y

\begin{tabular}{|l|c|c|l|}
\hline Item & Koefisien & Korelasi $(\mathrm{r})$ & Probabilitas \\
\hline $\mathrm{X}_{1} \cdot 1$ & 0,538 & 0,000 & Valid \\
\hline $\mathrm{X}_{1} \cdot 2$ & 0,557 & 0,000 & Valid \\
\hline $\mathrm{X}_{1} \cdot 3$ & 0,763 & 0,000 & Valid \\
\hline $\mathrm{X}_{1} \cdot 4$ & 0,785 & 0,000 & Valid \\
\hline $\mathrm{X}_{1} \cdot 5$ & 0,646 & 0,000 & Valid \\
\hline $\mathrm{X}_{1} \cdot 6$ & 0,686 & 0,000 & Valid \\
\hline \multicolumn{2}{|l|}{ Aplha Cronbach } & 0,730 & Reliabel \\
\hline
\end{tabular}


J. Nifanngeljau, M. Rifa'i dan N. I. Iriani/ Buana Sains Vol 19 No 2 : 53-78

\section{Analisis Deskriptif Variabel Penelitian}

Analisa data bertujuan untuk menjawab pertanyaan-pertanyaan peneliti dalam rangka mengungkap fenomene-fenomena sosial merupakan prodes menyederhanakan data ke dalam bentik yang lebih mudah dibaca dan diinterprestasikan. Oleh karena itu dapat disajikan gambaran hasil analisa data tentang masing-masing variabel dalam penelitian ini:

\section{Variabel Sumber Daya Manusia $\left(\mathrm{X}_{1}\right)$}

Analisa deskritif terhadap veriabel manusia $\left(\mathrm{X}_{1}\right)$ dalam penelitian ini dapat dilihat pada tabel 11 berikut ini:

Tabel 11. Distribusi Frekwensi

Variabel Sumber Daya Manusai $\mathrm{X}_{1}$

\begin{tabular}{|c|c|c|c|c|c|}
\hline & STS 1 & TS 2 & R 3 & S 4 & SS 5 \\
\hline $\mathrm{X}_{1} \cdot 1$ & 20 & 10 & 9 & 9 & 10 \\
\hline $\mathrm{X}_{1} \cdot 2$ & 1 & 3 & 32 & 17 & 5 \\
\hline $\mathrm{X}_{1} \cdot 3$ & 1 & 3 & 19 & 25 & 10 \\
\hline $\mathrm{X}_{1} \cdot 4$ & 9 & - & 9 & 25 & - \\
\hline $\mathrm{X}_{1} .5$ & 3 & 26 & - & 9 & 20 \\
\hline $\mathrm{X}_{1} \cdot 6$ & 12 & 3 & 24 & 16 & 3 \\
\hline
\end{tabular}

Keterangan:

$\mathrm{X}_{1} .1$ Apakah tingkat pendidikan sangat berperan penting dalam kalangan petani saat ini

$\mathrm{X}_{1} .2$ Apakah petani sangat membutuhkan pengalaman dalam bercocok tanam

$\mathrm{X}_{1} .3$ Apakah kemampuan sangat dibutuhkan dikalangan petani

$\mathrm{X}_{1} .4$ Apakah pelatihan sering dilaksanakan di kalangan petani

$\mathrm{X}_{1.5}$ Pelatihan diadakan di kalangan petani, apakah ada perubahan dalam melaksanakan cocok tanam
$\mathrm{X}_{1} .6$ Dengan ada adanya pelatihan, apakah ada perubahan pada saat panen hasil.

Item 1 mengenai tingkat pendidikan sangat berperan penting dalam kalangan petani saat ini responden yang menjawab sangat tidak setuju berjumlah 20 orang responden atau 34,5\%, jawaban responden tidak setuju berjumlah 10 orang responden atau $17,2 \%$, reponden yang menjawab ragu-ragu berjumlah 9 orang responden atau $15,5 \%$, responden yang menjawab setuju berjumlah 9 orang responden atau $15,5 \%$, sedangkan responden menjawab sangat setuju berjumlah 10 orang responden atau $17,2 \%$. Sehingga dapat disimpulkan bawa untuk tanggapan responen pada item 1 ke arah yang lebih baik.

Item 2 mengenai apakah petani sangat membutuhkan pengalam dalam bercocok tanam, responden yang menjawab sangat tidak setuju sebanyak 1 orang responden atau $1,7 \%$, reponden yang menjawab tidak setuju berjumlah 3 responden atau $5,2 \%$, responden yang menjawab raguragu berjumlah 32 responden atau $55,2 \%$, responden menjawab setuju berjumlah 17 responden atau 29,3\%, sedangkan responden menjawab sangta setuju berjumlah 5 responden atau $8,6 \%$. Sehingga dapat disimpulkan bawa untuk tanggapan responen pada item 2 ke arah yang lebih baik.

Item 3 mengenai apakah kemampuan sangat dibutuhkan dikalangan petani, responden yang menjawab sangat tidak setuju sebanyak 1 responden atau 1,7\%, jawaban responden tidak setuju 3 responden atau $5,2 \%$, reponden yang menjawab ragu-ragu berjumlah 19 responden atau $32,8 \%$, responden yang menjawab setuju berjumlah 25 responden atau 
$43,1 \%$, sedangkan responden menjawab sangat setuju berjumlah 10 responden atau $17,2 \%$. Sehingga dapat disimpulkan bawa untuk tanggapan responen pada item 3 ke arah yang lebih baik.

Item 4 mengenai apakah pelatihan sering dilaksanakan di kalangan petani responden yang menjawab sangat tidak setuju sebanyak 9 responden atau $15,5 \%$, reponden yang menjawab ragu-ragu berjumlah 24 responden atau $41,4 \%$, sedangkan responden yang menjawab setuju berjumlah 25 responden atau 43,1\%. Sehingga dapat disimpulkan bawa untuk tanggapan responen pada item 4 ke arah yang lebih baik.

Item 5 mengenai pelatihan diadakan di kalangan petani, apakah ada perubahan dalam melaksanakan cocok tanam responden yang menjawab sangat tidak setuju 5,2\%, reponden yang menjawab tidak setuju $44,8 \%$, responden yang menjawab setuju $15,5 \%$, sedangkan responden menjawab sangat $34,5 \%$. Sehingga dapat disimpulkan bawa untuk tanggapan responen pada item 5 ke arah yang lebih baik.

Item 6 mengenai dengan ada adanya pelatihan, apakah ada perubahan pada saat panen hasil responden yang menjawab sangat tidak setuju 20,7\%, responden yang menjawab tidak setuju 5,2\%, responden yang menjawab ragu-ragu $41,4 \%$, responden yang menjawab setuju 27,6\%, responden menjawab sangat setuju 5,2\%. Sehingga dapat disimpulkan bawa untuk tanggapan responen pada item 6 ke arah yang lebih baik.

\section{Variabel Sumber Daya Kapital $\left(\mathbf{X}_{2}\right)$}

Analisa deskritif terhadap veriabel Sumber Daya Kapital $\left(\mathrm{X}_{2}\right)$ dalam penelitian ini dapat dilihat pada tabel berikut ini:
Tabel 12. Distribusi Frekwensi Variabel Sumber Daya Kapital X 2

\begin{tabular}{|l|c|c|c|c|c|}
\hline & $\begin{array}{c}\text { STS } \\
1\end{array}$ & TS 2 & R 3 & S 4 & SS 5 \\
\hline $\mathrm{X}_{2 \cdot 1}$ & 12 & 4 & 9 & 22 & 11 \\
\hline $\mathrm{X}_{2} \cdot 2$ & 19 & 12 & 1 & 11 & 15 \\
\hline $\mathrm{X}_{2} \cdot 3$ & 12 & 4 & 9 & 22 & 11 \\
\hline $\mathrm{X}_{2} \cdot 4$ & 19 & 12 & 1 & 11 & 15 \\
\hline $\mathrm{X}_{2 \cdot 5}$ & 12 & 4 & 9 & 22 & 11 \\
\hline $\mathrm{X}_{2} \cdot 6$ & 2 & 6 & 13 & 27 & 10 \\
\hline
\end{tabular}

Keterangan:

$\mathrm{X}_{2} .1$ Apakah luas lahan dapat berpengaruh dalam penghasilan.

$\mathrm{X}_{2} .2$ Terjadinya perubahan iklim/cuaca apakah dapat berpengaruh proses panen hasil.

$\mathrm{X}_{2} .3$ Apakah bantuan pemerintah kepada petani berupa mesin pertanian.

$\mathrm{X}_{2} .4$ Adanya kebijakan pemerintah dikalangan petani, apakah bapak?Ibu menyetujui.

$\mathrm{X}_{2} .5$ Lahan merupakan SDA, apakah tidak yang tidak habis untuk melakukan aktivitas cocok tanam .

$\mathrm{X}_{2} .6$ Adanya mesin pertanian, apakah dapat melancarkan proses pengelolahan lahan.

Item 1 mengenai apakah luas lahan dapat berpengaruh dalam penghasilan, tanggapan responden dengan menjawab tidak sangat setuju berjumlah 12 responden atau 20,7\%, reponden yang menjawab tidak setuju berjumlah 4 responden atau 6,9\%, reponden yang menjawab ragu-ragu berjumlah 9 responden atau 15,5\%, responden yang mengatakan setuju berjumlah 22 responden atau 37,9\%, responden menjawab sangta setuju berjumlah 11 responden atau 19,0\%. Sehingga dapat disimpulkan bawa 
untuk tanggapan responen pada item 1 ke arah yang lebih baik.

Item 2 mengenai apakah terjadinya perubahan $\mathrm{iklim} /$ cuaca apakah dapat berpengaruh proses panen hasil, responden yang menjawab sangat tidak setuju berjumlah 19 responden atau 32,8\%, reponden yang menjawab tidak setuju berjumlah 12 responden atau 20,7\%, jawaban responden ragu-ragu berjumlah 1 responden atau 1,7\%, responden yang menjawab setuju berjumlah 11 responden atau 19,0\%, responden menjawab sangta setuju berjumlah 15 responden atau 25,9\%. Sehingga dapat disimpulkan bawa untuk tanggapan responen pada item 2 ke arah yang lebih baik.

Item 3 mengenai apakah bantuan pemerintah kepada petani berupa mesin pertanian, responden yang menjawab sangat tidak setuju berjumlah 12 responden atau 20,7\%, responden yang menjawab tidak setju berjumlah 4 responden atau $6,9 \%$, responden yang menjawab ragu-ragu berjumlah 9 responden atau $15,5 \%$, responden yang mengatakan setuju berjumlah 22 responden atau 37,9\%, responden mengatakan sangat setuju berjumlah 11 responden atau 19,0\%. Sehingga dapat disimpulkan bawa untuk tanggapan responen pada item 3 ke arah yang lebih baik.

Item 4 mengenai apakah kebijakan pemerintah dikalangan petani, apakah bapak?Ibu menyetujui responden yang menjawab sangat tidak setuju berjumlah 19 responden atau atau $32,8 \%$, responden yang menjawab tidak setuju 12 responden atau $20,7 \%$, responden yang mengtatakan ragu-ragu berjumlah 1 responden atau $1,7 \%$, responden yang menjawab setuju berjumlah 11 responden atau 19,0\%, responden menjawab sangta setuju berjumlah 15 responden atau $25,9 \%$. Sehingga dapat disimpulkan bawa untuk tanggapan responen pada item 4 ke arah yang lebih baik.

Item 5 mengenai lahan merupakan SDA, apakah tidak yang tidak habis untuk melakukan aktivitas cocok tanam responden yang menjawab sangat tidak setuju berjumlah 12 responden atau atau $20,7 \%$, responden yang menjawab tidak setuju 4 responden atau 6,9\%, responden yang mengtatakan raguragu berjumlah 9 responden atau $15,5 \%$, responden yang menjawab setuju berjumlah 22 responden atau $37,9 \%$, responden menjawab sangta setuju berjumlah 11 responden atau 19,0\%. Sehingga dapat disimpulkan bawa untuk tanggapan responen pada item 5 ke arah yang lebih baik.

Item 6 mengenai dengan ada adanya pelatihan, apakah adanya mesin pertanian, apakah dapat melancarkan proses pengelolahan lahan responden yang menjawab sangat tidak setuju berjumlah 2 responden atau atau $3,4 \%$, responden yang menjawab tidak setuju 6 responden atau $10,3 \%$, responden yang mengtatakan raguragu berjumlah 13 responden atau $22,4 \%$, responden yang menjawab setuju berjumlah 27 responden atau $46,6 \%$, responden menjawab sangta setuju berjumlah 10 responden atau $17,2 \%$. Sehingga dapat disimpulkan bawa untuk tanggapan responen pada item 6 ke arah yang lebih baik.

\section{Vaiabel Modal Sosial $\left(\mathbf{X}_{3}\right)$}

Analisa deskritif terhadap veriabel Modal Sosial $\left(\mathrm{X}_{3}\right)$ dalam penelitian ini dapat dilihat pada tabel berikut ini: 
Tabel 13. Distribusi Frekwensi Reabilitas Variabel Modal Sosial X 3

\begin{tabular}{|c|c|c|c|c|c|}
\hline & $\begin{array}{c}\text { STS } \\
1\end{array}$ & TS 2 & R 3 & S 4 & SS 5 \\
\hline $\mathrm{X}_{3.1}$ & 14 & 17 & 6 & 12 & 9 \\
\hline $\mathrm{X}_{3} \cdot 2$ & 1 & 26 & 4 & 24 & 3 \\
\hline $\mathrm{X}_{3.3}$ & 2 & 3 & 33 & 11 & 9 \\
\hline $\mathrm{X}_{3.4}$ & 4 & 18 & 14 & 10 & 12 \\
\hline $\mathrm{X}_{3.5}$ & 21 & 10 & 2 & 24 & 1 \\
\hline $\mathrm{X}_{3.6}$ & 21 & 6 & 8 & 7 & 16 \\
\hline
\end{tabular}

Keterangan:

$\mathrm{X}_{3.1}$ Apakah modal sosial yang menjadi kekuatan pengikak bagi kalangan masyarakat petani.

$\mathrm{X}_{3.2}$ Solidaritas, apakah sangat berpengaruh di kehidupan para petani .

$\mathrm{X}_{3} .3$ Apakah tolerensi sangat dibutuhkan. dikalangn kehidupan bermasyarakat

$\mathrm{X}_{3} .4$ Pemberdayaan (gotong royong) masyarakat adat apakh sangat dibutuhkan.

$\mathrm{X}_{3} .5$ Apakah budaya masyarakat terkandung nilai-nilai adat istiadat.

$\mathrm{X}_{3.6}$ Apakah diadakan kelembagaan di kalangan desa seperti KUD.

Item 1 mengenai modal sosial yang menjadi kekuatan pengikak bagi kalangan masyarakat responden yang menjawab sangat tidak setuju berjumlah 14 responden atau atau $24,1 \%$, responden yang menjawab tidak setuju 17 responden atau 29,3\%, responden yang mengtatakan raguragu berjumlah 6 responden atau $10,3 \%$, responden yang menjawab setuju berjumlah 12 responden atau $20,7 \%$, responden menjawab sangta setuju berjumlah 9 responden atau $15,5 \%$. Sehingga dapat disimpulkan bawa untuk tanggapan responen pada item 1 ke arah yang lebih baik.
Item 2 mengenai apakah solidaritas, apakah sangat berpengaruh di kehidupan para petani, responden yang menjawab sangat tidak setuju berjumlah 1 responden atau atau $1,7 \%$, responden yang menjawab tidak setuju 26 responden atau 44,8\%, responden yang mengtatakan raguragu berjumlah 4 responden atau $6,9 \%$, responden yang menjawab setuju berjumlah 24 responden atau $41,4 \%$, responden menjawab sangta setuju berjumlah 3 responden atau $5,2 \%$. Sehingga dapat disimpulkan bawa untuk tanggapan responen pada item 2 ke arah yang lebih baik.

Item 3 mengenai apakah tolerensi sangat dibutuhkan dikalangn kehidupan bermasyarakat, responden yang menjawab sangat tidak setuju berjumlah 2 responden atau atau $3,4 \%$, responden yang menjawab tidak setuju 3 responden atau 5,2\%, responden yang mengtatakan raguragu berjumlah 33 responden atau $56,9 \%$, responden yang menjawab setuju berjumlah 11 responden atau $19,0 \%$, responden menjawab sangta setuju berjumlah 9 responden atau 15,5\%. Sehingga dapat disimpulkan bawa untuk tanggapan responen pada item 3 ke arah yang lebih baik.

Item 4 mengenai apakah pemberdayaan (gotong royong) masyarakat adat apakh sangat dibutuhkan responden yang menjawab sangat tidak setuju berjumlah 4 responden atau atau $6,9 \%$, responden yang menjawab tidak setuju 18 responden atau $31,0 \%$, responden yang mengtatakan ragu-ragu berjumlah 14 responden atau $24,1 \%$, responden yang menjawab setuju berjumlah 10 responden atau $17,2 \%$, responden menjawab sangta setuju berjumlah 12 responden atau $20,7 \%$. Sehingga dapat disimpulkan bawa untuk tanggapan responen pada item 4 ke arah yang lebih baik. 
Item 5 mengenai pelatihan diadakan di kalangan petani, apakah budaya masyarakat terkandung nilainilai adat istiadat responden yang menjawab sangat tidak setuju berjumlah 21 responden atau atau $36,2 \%$, responden yang menjawab tidak setuju 10 responden atau $17,2 \%$, responden yang mengtatakan raguragu berjumlah 2 responden atau $3,4 \%$, responden yang menjawab setuju berjumlah 24 responden atau $41,4 \%$, responden menjawab sangta setuju berjumlah 1 responden atau $1,7 \%$. Sehingga dapat disimpulkan bawa untuk tanggapan responen pada item ke arah yang lebih baik.

Item 6 mengenai apakah diadakan kelembagaan di kalangan desa seperti KUD responden yang menjawab sangat tidak setuju $36,2 \%$, responden yang menjawab tidak setuju $10,3 \%$, responden yang menjawab ragu-ragu $13,8 \%$, responden yang menjawab tidak setuju $12,1 \%$, responden yang menjawab sangat setuju 27,6\%. Sehingga dapat disimpulkan bawa untuk tanggapan responen pada item 6 ke arah yang lebih baik.

\section{Variabel Sumber Sumber Daya Manusia $\left(\mathbf{X}_{4}\right)$}

Analisa deskritif terhadap veriabel Sumber Daya Alam $\left(\mathrm{X}_{4}\right)$ dalam penelitian ini dapat dilihat pada tabel 14 berikut ini:

Tabel 14. Distribusi Frekuensi Variabel Sumber Daya Alam X 4

\begin{tabular}{|c|c|c|c|c|c|}
\hline & $\begin{array}{c}\text { STS } \\
1\end{array}$ & TS 2 & R 3 & S 4 & SS 5 \\
\hline $\mathrm{X}_{4.1}$ & 13 & 4 & 7 & 23 & 11 \\
\hline $\mathrm{X}_{4.2}$ & 2 & 10 & 24 & 12 & 10 \\
\hline $\mathrm{X}_{4.3}$ & 13 & 4 & 7 & 23 & 11 \\
\hline $\mathrm{X}_{4.4}$ & 20 & 11 & 1 & 13 & 6 \\
\hline $\mathrm{X}_{4.5}$ & 10 & 9 & 8 & 23 & 8 \\
\hline $\mathrm{X}_{4.6}$ & 2 & 6 & 14 & 27 & 9 \\
\hline
\end{tabular}

Keterangan:

$\mathrm{X}_{4} .1 \quad$ Apakah kebijakan pemerintah sering, seperti diadakan Penyuluhan.

$\mathrm{X}_{4.2}$ Apakah bantuan pemerintah sering diadakan

$\mathrm{X}_{4.3}$ Pembangunan di desa seperti jalan tani apakah dapat bermanfaat.

$\mathrm{X}_{4} .4$ Apakah transportasi dapat berperan penting dikalangan petani.

$\mathrm{X}_{4.5}$ Apakah masyarakat/petani bekerja sama dengan pemerintah.

$\mathrm{X}_{4} 6$ Apakah masyarakat/petani bekerja sama dengan pemerintah.

Item 1 mengenai apakah kebijakan pemerintah sering, seperti diadakan Penyuluhan responden yang menjawab tidak sangat setuju sebanyak responden yang menjawab sangat tidak setuju berjumlah 13 responden atau atau $22,4 \%$, responden yang menjawab tidak setuju 4 responden atau $6,9 \%$, responden yang mengtatakan ragu-ragu berjumlah 7 responden atau $12,1 \%$, responden yang menjawab setuju berjumlah 23 responden atau $39,7 \%$, responden menjawab sangta setuju berjumlah 11 responden atau 19,0\%. Sehingga dapat disimpulkan bawa untuk tanggapan responen pada item 1 ke arah yang lebih baik.

Item 2 mengenai bantuan pemerintah sering diadakan, responden yang menjawab sangat tidak setuju berjumlah 2 responden atau atau 3,4\%, responden yang menjawab tidak setuju 10 responden atau $17,2 \%$, responden yang mengtatakan ragu-ragu berjumlah 24 responden atau $41,4 \%$, responden yang menjawab setuju berjumlah 12 responden atau 20,7\%, responden menjawab sangta setuju berjumlah 10 
responden atau $17,7 \%$. Sehingga dapat disimpulkan bawa untuk tanggapan responen pada item 2 ke arah yang lebih baik.

Item 3 mengenai apakah pembangunan di desa seperti jalan tani apakah dapat bermanfaat, responden yang menjawab sangat tidak setuju berjumlah 13 responden atau atau $22,4 \%$, responden yang menjawab tidak setuju 4 responden atau $6,9 \%$, responden yang mengtatakan raguragu berjumlah 7 responden atau $12,1 \%$, responden yang menjawab setuju berjumlah 23 responden atau $39,7 \%$, responden menjawab sangta setuju berjumlah 11 responden atau 19,0\%.Sehingga dapat disimpulkan bawa untuk tanggapan responen pada item 3 ke arah yang lebih baik.

Item 4 mengenai apakah transportasi dapat berperan penting dikalangan petani responden yang menjawab sangat tidak setuju berjumlah 20 responden atau atau $34,5 \%$, responden yang menjawab tidak setuju 11 responden atau 19,0\%, responden yang mengtatakan raguragu berjumlah 1 responden atau $1,7 \%$, responden yang menjawab setuju berjumlah 13 responden atau $22,4 \%$, responden menjawab sangta setuju berjumlah 6 responden atau $22,4 \%$. Sehingga dapat disimpulkan bawa untuk tanggapan responen pada item 4 ke arah yang lebih baik.

$$
\text { Item } 5 \text { mengenai }
$$

masyarakat/petani bekerja sama dengan pemerintah responden yang menjawab sangat tidak setuju berjumlah 10 responden atau atau $17,2 \%$, responden yang menjawab tidak setuju 9 responden atau 15,5\%, responden yang mengtatakan raguragu berjumlah 8 responden atau $13,8 \%$, responden yang menjawab setuju berjumlah 23 responden atau $39,7 \%$, responden menjawab sangta setuju berjumlah 8 responden atau
13,8\%.Sehingga dapat disimpulkan bawa untuk tanggapan responen pada item 5 ke arah yang lebih baik.

Item 6 mengenai apakah masyarakat/petani bekerja sama dengan pemerintah responden yang menjawab sangat tidak setuju berjumlah 2 responden atau atau $3,4 \%$, responden yang menjawab tidak setuju 6 responden atau $10,3 \%$, responden yang mengtatakan raguragu berjumlah 14 responden atau $24,1 \%$, responden yang menjawab setuju berjumlah 27 responden atau $46,6 \%$, responden menjawab sangat setuju berjumlah 9 responden atau 15,5\%. Sehingga dapat disimpulkan bawa untuk tanggapan responen pada item 6 ke arah yang lebih baik.

\section{Variabel Sumber Pendapatan Rumah Tangga Tani (Y)}

Analisa deskriptif terhadap veriabel Pendapatan Rumah Tangga Tani Y dalam penelitian ini dapat dilihat pada tabel 15 berikut ini:

Tabel 15. Distribusi Frekwensi Variabel

Pendapatan Rumah Tangga Tani Y

\begin{tabular}{|c|c|c|c|c|c|}
\hline & $\begin{array}{c}\text { STS } \\
1\end{array}$ & TS 2 & R 3 & S 4 & SS 5 \\
\hline Y.1 & 1 & 4 & 14 & 20 & 19 \\
\hline Y.2 & 3 & 7 & 10 & 26 & 12 \\
\hline Y.3 & - & 4 & 22 & 20 & 12 \\
\hline Y.4 & 7 & 20 & 2 & 16 & 13 \\
\hline Y.5 & 7 & 10 & 12 & 14 & 15 \\
\hline Y.6 & 3 & 9 & 15 & 16 & 15 \\
\hline
\end{tabular}


Keterangan:

Y.1 Luas lahan apakah dapat berpengaruh pada tingkat pendapatan rumah tangga tani.

Y.2 Perubahan cuaca apakah dapat berpengaruh pada tingkat pendapatan rumah tangga tani.

Y.3 Apakah lingkungan dapat berpengaruh pada tingkat pendapatan rumah tangga tani.

Y.4 Gotong royong apakah dapat berpengaruh pada tingkat pendapatan rumah tangga tani.

Y.5 Apakah Pendapatan rumah tangga tani semata-mata dari hasil pertanian.

Y.6 Kesejatran keluarga apakah dapat berpengaruh pada pendapatan rumah tangga tani.

Item 1 mengenai apakah luas lahan apakah dapat berpengaruh pada tingkat pendapatan rumah tangga tani responden yang menjawab tidak sangat setuju sebanyak 1 responden atau $1,7 \%$, jawaban responden tidak setuju 4 responden atau $6,9 \%$, reponden yang menjawab netral berjumlah 14 responden atau 24,1\%, responden yang mengatakan setuju berjumlah 20 responden atau 34,5\%, responden menjawab sangta setuju berjumlah 19 responden atau 32,8\%. Sehingga dapat disimpulkan bawa untuk tanggapan responen pada item 1 ke arah yang lebih baik.

Item 2 mengenai perubahan cuaca apakah dapat berpengaruh pada tingkat pendapatan rumah tangga tani responden yang menjawab sangat tidak setuju berjumlah 3 responden atau atau $5,2 \%$, responden yang menjawab tidak setuju 7 responden atau $12,1 \%$, responden yang mengtatakan ragu-ragu berjumlah 10 responden atau $17,2 \%$, responden yang menjawab setuju berjumlah 26 responden atau 44,8\%, responden menjawab sangat setuju berjumlah 12 responden atau 20,7\%. Sehingga dapat disimpulkan bawa untuk tanggapan responen pada item 2 ke arah yang lebih baik.

Item 3 mengenai apakah lingkungan dapat berpengaruh pada tingkat pendapatan rumah tangga tani, responden yang menjawab tidak setuju 4 responden atau $6,9 \%$, responden yang mengtatakan ragu-ragu berjumlah 22 responden atau $37,9 \%$, responden yang menjawab setuju berjumlah 20 responden atau $34,5 \%$, responden menjawab sangta setuju berjumlah 12 responden atau 20,7\%. Sehingga dapat disimpulkan bawa untuk tanggapan responen pada item 3 ke arah yang lebih baik.

Item 4 mengenai apakah gotong royong apakah dapat berpengaruh pada tingkat pendapatan rumah tangga responden yang menjawab sangat tidak setuju berjumlah 7 responden atau atau $12,1 \%$, responden yang menjawab tidak setuju 20 responden atau 34,5\%, responden yang mengtatakan raguragu berjumlah 2 responden atau $3,4 \%$, responden yang menjawab setuju berjumlah 16 responden atau $27,6 \%$, responden menjawab sangta setuju berjumlah 13 responden atau $22,4 \%$. Sehingga dapat disimpulkan bawa untuk tanggapan responen pada item 4 kearah yang lebih baik.

Item 5 mengenai pendapatan rumah tangga tani semata-mata dari hasil pertanian responden yang menjawab sangat tidak setuju berjumlah 7 responden atau atau $12,1 \%$, responden yang menjawab tidak setuju 10 responden atau $17,2 \%$, responden yang mengtatakan raguragu berjumlah 12 responden atau $20,7 \%$, responden yang menjawab setuju berjumlah 14 responden atau $24,1 \%$, responden menjawab sangta setuju berjumlah 15 responden atau $25,9 \%$. Sehingga dapat disimpulkan 
bawa untuk tanggapan responen pada item 5 ke arah yang lebih baik.

Item 6 mengenai apakah kesejatran keluarga apakah dapat berpengaruh pada pendapatan rumah tangga tani responden yang menjawab sangat tidak setuju berjumlah 3 responden atau atau $5,2 \%$, responden yang menjawab tidak setuju 9 responden atau $15,5 \%$, responden yang mengtatakan ragu-ragu berjumlah 15 responden atau $25,9 \%$, responden yang menjawab setuju berjumlah 16 responden atau $27,6 \%$, responden menjawab sangta setuju berjumlah 15 responden atau $25,9 \%$. Sehingga dapat disimpulkan bawa untuk tanggapan responen pada item 6 ke arah yang lebih baik.

\section{Uji Asumsi Klasik}

\section{Analisis Normalitas}

Uji normalitas digunakan untuk menditeksi apakah distribusi data variabel bebas dan variabel terikat adalah normal. Normalitas dapat diketaqhui dari normal probality plot, sedangkan model regresi yang baik adalah distribusi data normal. Adapun data yang dinyatakan normal jika data (titik) mengikuti dan membentuk garis lurus mendekati sudut $45^{\circ}$. Adapun untuk mengetahui data distribusi normal atau dilihat pada gambar normal P-Plot Of Regregesion Standarized Residual yang terdapat pada gambar 1.

\section{Analisis Multikolinearitas}

Model regresi yang baik seharusnya tidak terjadi korelasi di antara variabel-variabel independen. Apabila nilai VIF < 10 maka tidak terjadi multikoliniearitas dapat diambil keputusan bahwa pada model regresi dalam penelitian ini tidak terjadi multikoliniearitas. Nilai VIF pada X adalah 1,000 yang berarti lebih kecil dari 10. Sehingga dapat diambil kesimpulan bahwa ke tiga variabel mempunyai nilai VIF $<10$ yang berarti tidak terjadi multikolinearitas. Dari hasil perhitungan pada tabel 16 dapat diketahui bahwa hasil perhitungan nilai Tolerance menunjukkan tidak ada variabel independen yang memiliki nilai Tolerance kurang dari 0,10 yang berarti tidak ada korelasi antar variabel independen. Hasil perhitungan nilai Variance Inflation Factor (VIF) tidak ada variabel independen yang memiliki nilai VIF lebih dari 10. Sehingga, dapat disimpulkan bahwa tidak ada multikolinearitas antar variabel independen dalam model regresi penelitian ini.

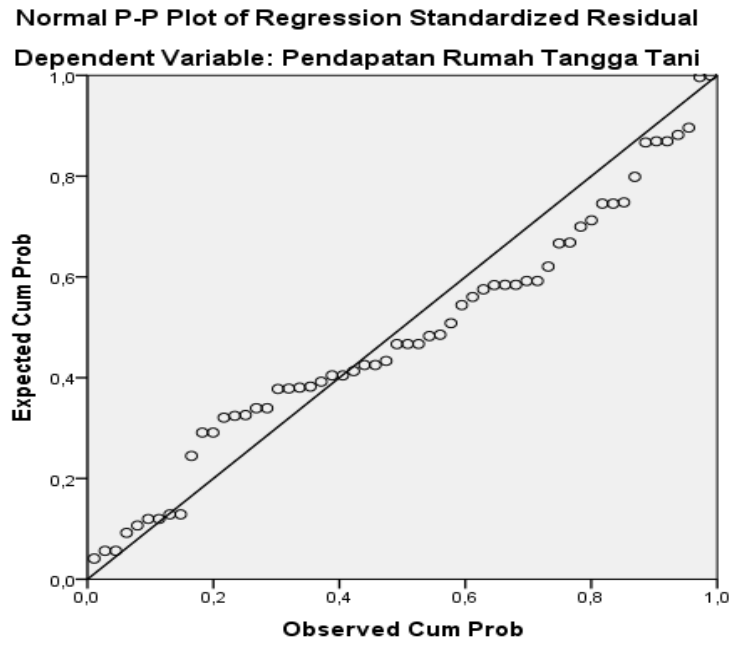

Gambar 1. Uji normalitas dengan bentuk P-Plot Of Regregesion Standarized Residual 
Tabel 16. Hasil Uji Asumsi Non Multikolinieritas

\begin{tabular}{|c|c|c|c|}
\hline Variabel & Tolerance & VIF & Keterangan \\
\hline $\mathrm{X}_{1}$ & 0,696 & 1,436 & Non Multikolinearitas \\
\hline $\mathrm{X}_{2}$ & 0,197 & 5,064 & Non Multikolinearitas \\
\hline $\mathrm{X}_{3}$ & 0,528 & 1,895 & Non Multikolinearitas \\
\hline $\mathrm{X}_{4}$ & 0,156 & 6,422 & Non Multikolinearitas \\
\hline
\end{tabular}

\section{Analisis Heteroskedstisitas}

Uji heteroskedastisitas digunakan untuk mengetahui ada atau tidaknya penyimpangan asumsi klasik heteroskedastisitas yaitu adanya ketidaksamaan varian dari residual untuk semua pengamatan pada model regresi. Heteroskedisitas merupakan suatu keadaan yaitu varian suatu pengamatan ke pengamatan yang lain berbeda. Prasyarat yang harus terpenuhi dalam model regresi adalah tidak adanya gejala heteroskedastisitas.

Untuk menggunakan SPSS 24 for Windows, heteroskedastisitas dapat diuji dengan melihat grafik Scatterplot. Untuk mendeteksi ada atau tidaknya heteroskedastisitas yaitu dengan melihat grafik plot antara variabel dependen yaitu ZPRED dengan residualnya ZRESID. Deteksi ada atau tidaknya heteroskedastisitas dapat dilakukan dengan melihat ada tidaknya pola tertentu pada grafik scatterplot antara ZRESID dan ZPRED dimana sumbu $\mathrm{Y}$ adalah $\mathrm{Y}$ yang telah diprediksi, dan sumbu $\mathrm{X}$ adalah residualnya.
Hasil uji ini dapat dilihat pada gambar 2. Melalui sebaran titik-titik pada grafik Scatterplot pada gambar di atas dapat dilihat dari sebaran titik-titik yang menyebar tidak membentuk pola di atas dan di bawah angka 0, sehingga dapat disimpulkan pada model regresi dalam penelitian ini tidak terjadi heteroskedastisitas.

\section{Analisis Autokorelasi}

Menurut Suwarjeni (2015) menguji autokorelasi dalam suatu model bertujuan untuk mengetahui ada tidaknya korelasi antara variabel pengganggu pada periode tertentu dengan variabel sebelumnya. Untuk data time series autokorelasi sering terjadi. Tapi untuk data yang sampelnya crossection jarang terjadi karena variabel pengganggu satu berbeda dengan yang lain. Mendeteksi autokorelasi dengan menggunakan nilai Durbin Watson dengan kriteria jika: Angka D-W dibawah -2 berarti ada autokorelasi positif Angka D-W diantara -2 dan +2 berarti tidak ada autokorelasi. Angka D-W diatas +2 berarti ada autokorelasi negatif.

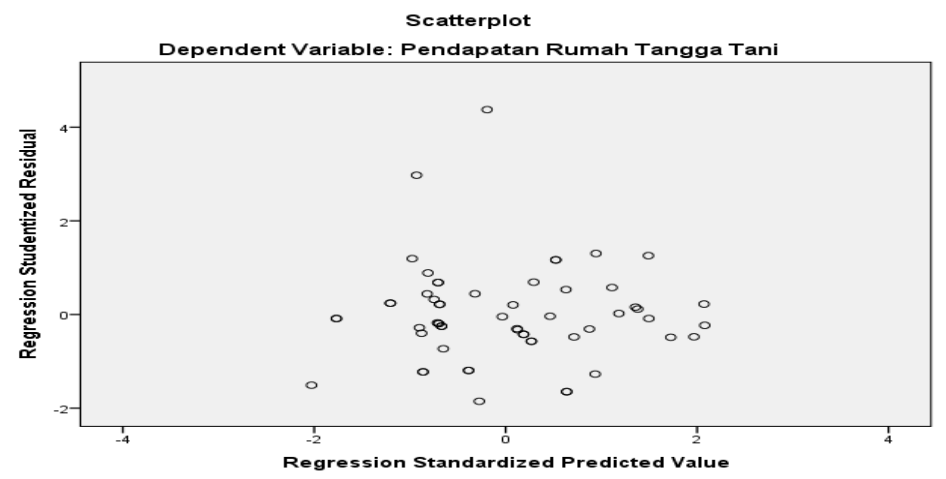

Gambar 2. Analisis Heteroskedastisitas yang diuji dengan grafik Scatterplot 
Dari data didapatkan bahwa nilai Durbin-Watson sebesar 1,599, karena nilai Dw terletak di antara DU dan 4 DU $\quad(1,725<1,686<1,1469)$ kesimpulannya tidak terjadi autokorelasi dalam regresi ini.

\section{Analisa Regresi}

Analisis regresi digunakan untuk melakukan prediksi bagaimana perubahan nilai variabel dependen bila nilai variabel independen dinaikan atau diturunkan. Pada penelitian ini ada satu variabel independen dan satu variabel dependen. Variabel bebas dalam penelitian ini yaitu Sumber Daya Manusia $\left(\mathrm{X}_{1}\right)$ Sumber Daya Kapital $\left(\mathrm{X}_{2}\right)$, Modal Sosial $\left(\mathrm{X}_{3}\right)$ dan Sumber Daya Alam $\left(\mathrm{X}_{4}\right)$ sedangkan variabel terikatnya adalah Pendapatan Rumah Tangga Tani (Y).

Berdasarkan tabel 16. dapat diketahui bahwa nilai estimasi regresi pada kolom Beta dibuat model regresi linier adalah sebagai berikut:

$$
\begin{gathered}
\mathrm{Y}=\mathrm{b}_{1} \mathrm{X}_{1}+\mathrm{b}_{1} \mathrm{X}_{2}+\mathrm{b}_{3} \mathrm{X}_{3}+\mathrm{b}_{4} \mathrm{X}_{4} \\
\mathrm{Y}=0,001 \mathrm{X}_{1}+0,343 \mathrm{X}_{2} 0,028 \mathrm{X}_{3}+0,581 \mathrm{X}_{4}
\end{gathered}
$$

Berdasarkan nilai pada persamaan tersebut maka dapat diinterpretasikan sebagai berikut:

$\mathrm{Y}=$ Merupakan variabel terikat yang nilainya akan diprediksi oleh variabel bebas. Pada penelitian ini yang menjadi variabel terikat adalah Pendapatan Rumah Tangga Tani yang nilainya akan diprediksi oleh variabel adalah Sumber Daya Manusia(X1), Sumber Daya Kapital (X2), Modal Sosial(X3) dan Sumber Daya Alam (X4) b1 = Koefisien regresi variabel Sumber Daya manusia (X1) sebesar 0,701 memiliki tanda positif yang menunjukkan bahwa variabel ini berpengaruh signifikan terhadap Pendapatan Rumah Tangga Tani (Y). Apabila terdapat peningkatan Sumber Daya Manusia (X1) maka akan terjadi peningkatan pada Pendapatan Rumah Tangga Tani (Y) dengan asumsi variabel yang lain dianggap tetap atau sama dengan 0 . Pada variabel Sumber Daya Manusia (X1) ini mempunyai Sig.t sebesar $\quad 0,000 \quad$ artinya berpengaruh signifikan terhadap Pendapatan Rumah Tangga Tani $(\mathrm{Y})$ karena Sig.t $<$ 0,05 .

b2 $=$ Koefisien regresi variabel Sumber Daya Kapital (X2) sebesar 0,341 memiliki tanda positif yang menunjukkan bahwa variabel ini berpengaruh signifikan terhadap Pendapatan Rumah Tangga Tani (Y). Apabila terdapat peningkatan pada Sumber Daya Kapital (X2) maka akan terjadi pada Pendapatan Rumaha Tangga Tani (Y) dengan asumsi variabel yang lain dianggap tetap atau sama dengan 0 . Pada variabel Sumber Daya Kapital (X2) ini mempunyai Sig.t sebesar 0,001 artinya tidak berpengaruh signifikan terhadap Pendapatan Rumah Tangga Tani (Y) karena Sig.t $>0,05$.

b3 $=$ Koefisien regresi variabel Modal Sosial (X3) sebesar 0,028 memiliki tanda positif yang menunjukkan bahwa variabel ini tidak berpengaruh terhadap Pendapatan Rumah Tangga Tani (Y). Apabila terdapat peningkatan pada 
Modal Sosial (X3) maka akan terjadi peningkatan pada Pendapatan Rumah Tangga Tani (Y) dengan asumsi variabel yang lain dianggap tetap atau sama dengan 0 . Pada variabel Modal Sosial (X3) ini mempunyai Sig.t sebesar 0,732 artinya berpengaruh tidak berpengaruh signifikan terhadap Pendapatan Rumah Tangga Tani (Y) karena Sig.t $>0,05$.

b4 $=$ Koefisien regresi variabel Sumber Daya Alam (X4) sebesar 0,581 memiliki tanda positif yang menunjukkan bahwa variabel ini berpengaruh signifikan terhadap Pendapatan Rumah Tangga Tani (Y). Apabila terdapat peningkatan pada Sumber Daya Alam (X4) maka akan terjadi peningkatan pada Pendapatan Rumah Tangga Tani (Y) dengan asumsi variabel yang lain dianggap tetap atau sama dengan 0. Pada variabel Sumber Daya Alam (X4) ini mempunyai Sig.t sebesar 0,000 artinya berpengaruh signifikan terhadap Pendapatan Rumah Tangga Tani (Y) karena Sig.t $>$ 0,05 .

\section{Analisis Koefisien Diterminasi}

Koefisien Determinasi diartikan sebagai seberapa besar kemampuan variabel bebas memberikan peranan pada variabel terikatnya. Koefisien determinasi dihitung dengan mengkuadratkan koefisien korelasi $\left(\mathrm{R}^{2}\right)$. Dalam hal ini untuk mengetahui besarnya peranan yang diberikan Sumber Daya Manusia $\left(\mathrm{X}_{1}\right)$, Sumber Daya Kapital $\left(\mathrm{X}_{2}\right)$, Modal Sosial $\left(\mathrm{X}_{3}\right)$ dan Sumber Daya
Alam $\left(\mathrm{X}_{4}\right) \quad$ terhadap Pendapatan Rumah Tangga Tani (Y).

Dari data yang diperoleh didapatkan nilai koefisien determinasi yang diperoleh adalah 0,866 atau $86,6 \%$. Hasil tersebut menunjukkan bahwa Sumber Daya Manusia $\left(\mathrm{X}_{1}\right)$, Sumber Daya Kapital $\left(\mathrm{X}_{2}\right)$, Modal Sosial $\left(\mathrm{X}_{3}\right)$ dan Sumber Daya Alam $\left(\mathrm{X}_{4}\right)$ memberikan pengaruh sebesar 86,6\% terhadap Kinerja (Y).

\section{a. Uji Hipotesis}

Model regresi yang telah didapatkan diuji terlebih dahulu baik secara simultan dan secara parsial, Pengujian model regresi secara simultan dilakukan dengan menggunakan uji $\mathrm{F}$ atau ANOVA dan pengujian model regresi secara parsial dilakukan dengan uji t.

\section{Uji F}

Pengujian secara simultan dilakukan untuk menunjukkan apakah semua variabel bebas yang terdiri dari Sumber Daya Manusia $\left(\mathrm{X}_{1}\right)$, Sumber Daya Kapital $\left(\mathrm{X}_{2}\right)$, Modal Sosial $\left(\mathrm{X}_{3}\right)$ dan Sumber Daya Alam $\left(\mathrm{X}_{4}\right)$ memiliki pengaruh yang signifikan secara simultan terhadap variabel terikat keputusan pembelian $(\mathrm{Y})$.

Dari data didapatkan bahwa nilai $\mathrm{F}$ hitung 39,816. Berdasarkan hasil pengujian hipotesis model regresi secara simultan atau secara serentak menggunakan uji $\mathrm{F}$ dapat dilihat Fhitung lebih besar daripada Ftabel $(39,816 .>3,156)$ dan signifikansi sebesar 0,000 yang berarti lebih kecil dari alpha $(a)=0,05$. Sehingga dapat disimpulkan bahwa $\mathrm{H} 0$ ditolak dan $\mathrm{Ha}$ diterima, artinya terdapat pengaruh secara parsial antara bahwa Sumber Daya Manusia $\left(\mathrm{X}_{1}\right)$, Sumber Daya Kapital $\left(\mathrm{X}_{2}\right)$, Modal Sosial $\left(\mathrm{X}_{3}\right)$ Sumber Daya Alam $\left(\mathrm{X}_{4}\right)$ terhadap variabel Pendapatan Rumah Tangga Tani $(Y)$. 
2. Uji t

a. Variabel Sumber Daya Manusia $\left(\mathrm{X}_{1}\right)$

Berdasarkan Tabel di atas pengujian hipotesis koefisien regresi variabel. Variabel $\mathrm{X}_{1}$ memiliki koefisien regresi sebesar 0,710 dan didapatkan statistik uji t sebesar 8,264 dengan nilai signifikean sebesar 0,000 . Nilai statistik uji thitung tersebut lebih besar daripada ttabel $(8,264>1,672)$ dan nilai signifikean lebih kecil daripada $a=0,05$. Pengujian ini menunjukkan bahwa $\mathrm{Ha}$ diterima, dan dapat disimpulkan bahwa variabel Sumber Daya Manusia $\left(\mathrm{X}_{1}\right)$ berpengaruh signifikan terhadap variabel Pendapatan rumah tangga Tani $(\mathrm{Y})$.

\section{b. Sumber Daya Kapital $\left(\mathbf{X}_{2}\right)$}

Berdasarkan tabel di atas pengujian hipotesis koefisien regresi variabel

Sumber Daya Kapital $\left(\mathrm{X}_{2}\right)$ memiliki koefisien regresi sebesar 0,343 dan didapatkan statistik uji t sebesar 3,402 dengan nilai signifikan sebesar 0,001 . Nilai statistik uji thitung tersebut lebih besar daripada ttabel $(3,402>1,672)$ dan nilai signifikan lebih besar dari pada $a=0,05$. Pengujian ini menunjukkan bahwa Ha diterima, dan dapat disimpulkan bahwa variabel Sumber Daya Kapital $\left(\mathrm{X}_{2}\right)$ berpengaruh secara signifikan terhadap variabel Pendapatan Rumah Tangga Tani $(\mathrm{Y})$.

\section{c. Modal Sosial $\left(\mathrm{X}_{3}\right)$}

Berdasarkan tabel di atas pengujian hipotesis koefisien regresi variabel

Sumber Modal Sosial $\left(\mathrm{X}_{3}\right)$ memiliki koefisien regresi sebesar 0,028 dan didapatkan statistik uji t sebesar 0,344 dengan nilai signifikan sebesar 0,732 . Nilai statistik uji thitung tersebut lebih besar daripada ttabel $(0,344<1,672)$ dan nilai signifikan lebih besar dari pada $a=0,05$. Pengujian ini menunjukkan bahwa Ha diterima, dan dapat disimpulkan bahwa variabel Modal Sosial $\left(\mathrm{X}_{3}\right)$ dapat berpengaruh signifikan terhadap variabel Pendapatan Rumah Tangga Tani (Y).

\section{d. Sumber Daya Alam $\left(\mathbf{X}_{4}\right)$}

Berdasarkan tabel di atas pengujian hipotesis koefisien regresi variabel

Sumber Sumber Daya Alam $\left(\mathrm{X}_{4}\right)$ memiliki koefisien regresi sebesar 0,581 dan didapatkan statistik uji $\mathrm{t}$ sebesar 4,096 dengan nilai signifikan sebesar 0,000 . Nilai statistik uji thitung tersebut lebih besar daripada tabel $(4,096>1,67)$ dan nilai signifikean lebih kecil dari pada $a=0,05$. Pengujian ini menunjukkan bahwa Ha diterima, dan dapat disimpulkan bahwa variabel Sumber Daya Alam $\left(\mathrm{X}_{4}\right)$ dapat berpengaruh signifikan terhadap variabel Pendapatan Rumah Tangga Tani $(Y)$.

\section{e. Uji Dominan}

Untuk menentukan variabel independen yang paling berpengaruh terhadap variabel $\mathrm{Y}$, dapat dilakukan dengan membandingkan koefisien regresi $(\beta)$ antara variabel yang satu dengan yang lain. Variabel independen yang paling dominan pengaruhnya terhadap variabel $\mathrm{Y}$ adalah variabel yang memiliki koefisien regresi yang paling besar.

Berdasarkan hasil uji dominan didapatkan variabel Sumber Daya Manusai $\left(\mathrm{X}_{1}\right)$ adalah variabel yang memiliki koefisien regresi yang paling besar. Artinya dalam penelitian ini, Pendapata Rumah Tangga Tani (Y) lebih banyak dipengaruhi oleh variabel Sumber Daya Manusia $\left(\mathrm{X}_{1}\right)$ daripada variabel Sumber Daya Kapital $\left(\mathrm{X}_{2}\right)$. Koefisien yang dimiliki oleh variabel $\left(\mathrm{X}_{2}\right)$ bertanda positif, hal ini menunjukkan hubungan yang searah 
yang berarti belum efektif Sumber Daya Kapital $\left(\mathrm{X}_{2}\right)$ yang mencakup atau peningkatkan pada Pendapatan Rumah Tangga Tani (Y). Koefisien yang dimiliki oleh variabel Modal Sosial $\left(\mathrm{X}_{3}\right)$ bertanda positif, hal ini menunjukkan hubungan yang searah yang berarti semakin baik Modal Sosial $\left(\mathrm{X}_{3}\right)$ yang mencakup atau peningkatkan pada Pendapatan Rumah Tangga Tani (Y). Koefisien yang dimiliki oleh variabel Sumber Alam $\left(\mathrm{X}_{4}\right)$ bertanda positif, hal ini menunjukkan hubungan yang searah yang berarti belum membaik Sumber Daya Sumber Daya Alam $\left(\mathrm{X}_{4}\right)$ yang mencakup atau peningkatkan pada Pendapatan Rumah Tangga Tani (Y).

\section{Pengaruh Sumber Daya Manusia Terhadap Pendapatan Rumah tangga Tani}

Hasil pengujian hipotesis menunjukkan bahwa Sumber Daya Manusia berpengaruh signifikan terhadap Pendapatan Rumah Tangga Tani. Hal tersebut ditunjukkan oleh nilai koefisien sebesar 0,701 dengan probabilitas sebesar $0,000 \quad(p>0,05)$. Berdasarkan analisis data yang dilakukan dalam penelitian ini terdapat pengaruh signifikan antara Sumber Daya Manusia terhadap Pendapatan Rumah Tangga Tani. Hasil dari penelitian ini penelitian ini sejalan dengan penelitian

Khanisa (2003) menyatakan adanya perbedaan pendapat pada setiap luas lahan, semakin luas lahan pertanian pendapatan semakin tinggi. pada penelitian ini juga sejalan dengan Pendekatan ini digunakan di antaranya oleh Ersado (2003), Anderson dan Deshingkar (2005), Minot et al. (2006), dan Zhao dan Barry (2013). Bisa jadi satu rumah tangga memiliki indeks diversifikasi yang sama dengan rumah tangga lain, padahal jenis sumber pendapatan keduanya berbeda.
Sebagai contoh, rumah tangga pertama lebih berdiversifikasi ke jenis-jenis usaha pertanian (usaha ternak, usaha perkebunan, buruh tani, dan sebagainya), sementara rumah tangga yang lain lebih berdiversifikasi ke kegiatan nonpertanian (jasa nonpertanian, buruh nonpertanian, pekerja profesional, dan sebagainya). Oleh karenanya, indeks ini akan lebih berguna jika dilengkapi dengan informasi jenis-jenis sumber pendapatan rumah tangga.

\section{Pengaruh Sumber Daya Kapital Terhadap Pendapatan Rumah tangga Tani}

Hasil pengujian hipotesis menunjukkan bahwa Sumber Daya Kapital tidak berpengaruh signifikan terhadap Pendapata Rumah Tangga Tani di Desa Jonrejo Kecamatan Tlekung Kota Batu. Hal tersebut ditunjukkan oleh nilai koefisien sebesar 0,343 dengan probabilitas sebesar 0,001 (p 0,071<0,05). Hasil uji ini menunjukkan bahwa variabel Sumber Daya Kapital berpengaruh signifikan terhadap Pendapata Rumah Tangga Tani di Desa Jonrejo Kecamatan Tlekung Kota Batu. Hasil penelitian ini sejalan dengan penelitian terdahulu yang dilakukan Menurut Gustiyana (2003), pendapatan dapat dibedakan menjadi dua yaitu pendapatan usahatani dan pendapatan rumah tangga. Pendapatan merupakan pengurangan dari penerimaan dengan biaya total. Pendapatan rumah tangga adalah pendapatan yang dapat diperoleh dari kegiatan usahatani, ditambah dengan pendapatan-pendapatan yang berasal dari kegiatan lain diluar usahatani. Pendapatan usahatani adalah selisih antara pendapatan kotor (output) dan biaya produksi (input) yang dihitung dalam perbulan, pertahun, permusim tanam. Pendapatan luar usahatani 
adalah pendapatan yang diperoleh dari berbagai aktivitas dalam melakukan kegiatan diluar usahatani seperti berdagang.

Menurut Sukirno (2005) pendapatan adalah jumlah penghasilan yang diterima oleh penduduk atas prestasi kerjanya selama satu periode tertentu, baik harian, mingguan, bulanan maupun tahunan. Dewasa ini sumber pendapatan sebagian besar rumah tangga di pedesaan tidak hanya dari satu sumber, melainkan dari beberapa sumber atau dapat dikatakan rumah tangga melakukan diversifikasi pekerjaan atau memiliki aneka ragam sumber pendapatan

\section{Modal Sosial Terhadap Pendapatan Rumah tangga Tani}

Hasil pengujian hipotesis menunjukkan bahwa Sumber Daya Kapital tidak berpengaruh signifikan terhadap Pendapata Rumah Tangga Tani di Desa Jonrejo Kecamatan Tlekung Kota Batu. Hal tersebut ditunjukkan oleh nilai koefisien sebesar 0,028 dengan probabilitas sebesar 0,344 (p 0,732>0,05). Hasil uji ini menunjukkan bahwa variabel Sumber Daya Kapital berpengaruh pengaruh signifikan terhadap Pendapata Rumah Tangga Tani di Desa Jonrejo Kecamatan Tlekung Kota Batu. Hasil penelitian ini sejalan dengan penelitian terdahulu yang dilakukan oleh Purwadi (2004), sudah terbentuk sebelum abad 17. Walaupun tidak semua tingkat kehidupan masyarakat di keempat desa contoh mengalami kemajuan, atau setidaktidaknya ada yang kemajuannya mengalami masa pasang surut, namun secara sosio historis masyarakat di keempat desa contoh memliki kekuatan untuk tetap bertahan hidup dan sekaligus menghindarkan diri dari proses pemunahan secara alami.
Hal menunjukkan bahwa keberadaan masyarakat pedesaan tidak sekedar adanya sekumpulan manusia yang secara fisik telah hidup bersama dalam kurun tertentu, melainkan ada "semangat" atau ruh sosial yang menjadi kekuatan pengikat kehidupan kolektif mereka. Kekuatan budaya nonmaterial atau modal sosial menjadi faktor penting mengapa masyarakat di keempat desa contoh hingga sekarang masih bisa bertahan. Terpenuhinya kebutuhan pangan merupakan hal yang esensial bagi kehidupan masyarakat pedesaan. Namun demikian di keempat desa contoh hampir tidak ditemukan terjadi konflik dengan kekerasan yang diakibatkan oleh kurang tercukupi kebutuhan bahan pangan. Juga nyaris tidak terlihat gejala penghancuran solidaritas sosial akibat masyarakat mengalami kesulitan dalam pemenuhan kebutuhan dasarnya.

\section{Pengaruh Sumber Daya Alam Terhadap Kinerja}

Hasil pengujian hipotesis menunjukkan bahwa Sumber Daya Alam tidak berpengaruh signifikan terhadap Pendapata Rumah Tangga Tani di Desa Jonrejo Kecamatan Tlekung Kota Batu. Hal tersebut ditunjukkan oleh nilai koefisien sebesar 0,581 dengan probabilitas sebesar 0,000, (p 0,581<0,05). Hasil uji ini menunjukan bahwa variabel Sumber Daya Alam berpengaruh signifikan terhadap Pendapata Rumah Tangga Tani di Desa Jonrejo Kecamatan Tlekung Kota Batu. Hasil penelitian ini sejalan dengan penelitian terdahulu yang sejalan dengan Theodore Schultz (dalam Fitzenz, 2009), peningkatan kesejahteraan kaum miskin tidak tergantung pada tanah, peralatan atau energi namun tergantung pada pengetahuan. 
J. Nifanngeljau, M. Rifa’i dan N. I. Iriani/ Buana Sains Vol 19 No 2 : 53-78

Human capital merupakan kombinasi antara sifat (intelejensi, energi, sikap, reliabilitas dan komitmen), kemampuan belajar (bakat, imajinasi, kreativitas dan kecerdikan) dan motivasi untuk berbagi informasi dan pengetahuan. penelitian ini sejalan dengan Present $V$ alue ini apabila pendidikannya hanya sampai SMA atau melanjutkan kuliah di perguruan tinggi sebelum bekerja. Seorang tamatan SMA akan memperoleh pendapatan dengan segera pada usia 18 tahun sedangkan bagi tamatan perguruan tinggi akan memilih kuliah terlebih dahulu baik D3 atau S1 dengan harapan pada masa yang akan datang memperoleh penghasilan yang lebih tinggi (Atmanti, 2005: 31).

\section{Kesimpulan}

Penelitian ini dilakukan untuk mengetahui perngaruh variabel independen yang terdiri dari Sumber Daya Alam, Sumber Daya Kapital, Modal Sosial dan Sumber Daya Manusia terhadap variabel terikat Pendapatan Rumah Tangga Tani. Berdasarkan hasil analisis regresi linier berganda, maka dapat disimpulkan sebagai berikut:

1. Sumber Daya Manusia berpengaruh signifikan terhadap Pendapatan Rumah Tangga Tani. Hal ini dibuktikan melalui nilai koefisien sebesar 0,701 atau atau sebesar $70,1 \%$ dan probabilitas sebesar 0,000 ( $p>0,05)$.

2. Sumber Daya Kapital berpengaruh signifikan terhadap Pendapatan Rumah Tangga Tani. Hal ini dibuktikan melalui nilai koefisien sebesar 0,343 atau sebesar $\quad 34,3 \% \quad$ dengan probabilitas sebesar 0,001 $(\mathrm{p}>0,05)$

3. Modal Sosial tidak berpengaruh signifikan terhadap Pendapatan
Rumah Tangga Tani. Hal ini dibuktikan nilai koefisien nilai koefisien sebesar 0,028 atau sebesar 2,8\% dengan probabilitas sebesar 0,344 $(p<0,05)$

4. Sumber Daya Alam berpengaruh signifikan terhadap Pendapatan Rumah Tangga Tani. Hal ini dibuktikan nilai koefisien sebesar 0,581 atau sebesar 58,1\% dengan probabilitas sebesar 0,000 $(\mathrm{p}>0,05)$

5. Secara parsial atau suatu keseluruhasn Sumber Daya Alam, Sumber Daya Kapital, Modal Sosial dan Sumber Daya Manusia tidak berpengaruh signifikan terhadap Pendapatan Rumah Tangga tani. Hal ini dibuktikan melalui nilai signifikansi $\mathrm{F}$ sebesar $0,040$ ( $p>0,05)$. Besar pengaruh variabel Sumber Daya Alam, Sumber Daya Kapital, Modal Sosial dan Sumber Daya Manusia dalam mempengaruhi Pendapata Rumah Tangga Tani di Desa Jonrejo Kecamatan Tlekung Kota Batu melalui nilai $\mathrm{R}$ Square sebesar 0,172 atau $17,2 \%$ dimana nilai ini menunjukkan pengaruh yang tidak terlalu besar pada variabel terikat ini., sedangkan yang sisanya sebesar dipengaruhi oleh variabel lain di luar model penelitian ini.

\section{DAFTAR PUSTAKA}

Arikunto, Suharsimi. 2013. Prosedur Penelitian: Suatu Pendekatan Praktik. Jakarta: Rineka Cipata

Atmanti, H. D. 2005. Investasi Sumber Daya Manusia Melalui Pendidikan. Dinamika Pembangunan, 31.

Asnawi \& Masyhuri. 2011. Metodologi Riset Manajemen Pemasaran. Malang: UIN Maliki Press 
Bilson Simamora. (2004). Panduan Riset Perilaku Konsumen. Jakarta: PT. Gramedia Pustaka Utama

Gustiyana, H. 2003. Analisis Pendapatan Usahatani untuk Produk Pertanian. Salemba empat. Jakarta.

Fukuyama, Francis. 2000. Social Capital dalam Lawrence E.Harrion dan Samuel P. Hungtington, eds. Culture Matters; How Values Shape Human Progress. New York; Basic Book.

Fitz-enz,Jac. (2009). The ROI of Human Capital: Measuring The Economic Value Of Employee Performance (2nd ed.). New York: Amacom.

Siregar, Syofian. 2013. Metode Penelitian Kuantitatif. Jakarta: PT Fajar Interpratama Mandiri.

Purwadi. 2004. Proses Pembentukan Identitas Diri Remaja. Jurnal Humanitas: Indonesian Psychologycal Journal Vol.1 No.1

Sukirno, Sadono. 2005. Mikro Ekonomi, Teori Pengantar. Penerbit PT. Raja Grafindo Persada, Jakarta.

Ulber, Silalahi. 2009. Metode Penelitian Sosial. Bandung: PT. Refika Aditama. 
